\title{
Effects of genotype, salt content and calibre on quality of traditional dry-fermented sausages
}

\author{
Marta Laranjo a , Ana Cristina Agulheiro-Santos ${ }^{\text {a, b }}$, Maria Eduarda Potes ${ }^{\text {a, c }}$, \\ Maria João Cabrita ${ }^{\text {a, b }}$, Raquel Garcia a , Maria João Fraqueza ${ }^{\text {d }}$, Miguel Elias ${ }^{\text {a, b, * }}$ \\ a ICAAM-Instituto de Ciências Agrárias e Ambientais Mediterrânicas, Instituto de Investigação e Formação Avançada (IIFA), Universidade de Évora, \\ Núcleo da Mitra, Ap. 94, 7006-554 Évora, Portugal \\ ${ }^{\mathrm{b}}$ Departamento de Fitotecnia, Escola de Ciências e Tecnologia, Universidade de Évora, Núcleo da Mitra, Ap. 94, 7006-554 Évora, Portugal \\ ${ }^{c}$ Departamento de Medicina Veterinária, Escola de Ciências e Tecnologia, Universidade de Évora, Núcleo da Mitra, Ap. 94, 7006-554 Évora, Portugal \\ d CIISA, Faculdade de Medicina Veterinária, Universidade de Lisboa, Avenida da Universidade Técnica, Polo Universitário do Alto da Ajuda, $1300-477$ Lisboa, \\ Portugal
}

\section{A R T I C L E I N F O}

\section{Article history:}

Received 16 November 2014

Received in revised form

17 March 2015

Accepted 18 March 2015

Available online 27 March 2015

\section{Keywords:}

Dry-fermented meat sausages

Food safety

Salt content

Fatty acids profile

Texture

Sensory analysis

\begin{abstract}
A B S T R A C T
The increasing demand for traditional food products is concomitant with higher nutritional and health concerns. The effect of genotype, salt content and calibre on physicochemical, microbiological and texture parameters, along with sensory acceptability, was studied on low-salt Portuguese traditional dryfermented sausages. A few significant differences were found in different microbial counts between different pork genotypes' sausages. Lauric and stearic fatty acids showed significantly higher values for hybrid genotype products, while contents in gadoleic, heneicosanoic, linoleic and linolenic acids were higher in Alentejano pork sausages. Unexpectedly, there are no significant differences between genotypes for oleic acid, although lower contents were found in the Alentejano genotype. Texture Profile Analysis revealed significant differences in hardness, adhesiveness, resilience and chewiness between genotypes, with Alentejano pork sausages being softer and thus easier to chew. Salt reduction does not negatively affect the quality and acceptability of sausages. Furthermore, the use of hybrid genotype meat does not mischaracterise a product traditionally made exclusively of Alentejano pig meat.
\end{abstract}

() 2015 Published by Elsevier Ltd.

\section{Introduction}

The manufacture of dry-fermented sausages represents an important part of the European meat industry, particularly in Mediterranean countries, such as Portugal, Spain, France, Italy and Greece (Comi et al., 2005; Talon et al., 2012). In Portugal, the production of a wide variety of Portuguese traditional dry-cured sausages amounted to 78,933 t in 2011 (INE., 2012). Such products are highly appreciated by consumers and are considered of high sensory quality.

Meat salting and ripening by dehydration are two of the oldest methods of preservation, with modification and increase of its organoleptic properties (Farkas, 2007; Montville \& Chikindas, 2007). Dry-fermented meat products have often been accused of

\footnotetext{
* Corresponding author. Universidade de Évora, Departamento de Fitotecnia, Núcleo da Mitra, Ap. 94, 7006-554 Évora, Portugal.

E-mail address: elias@uevora.pt (M. Elias).
}

having high salt and fat contents (Desmond, 2006; Muguerza, Gimeno, Ansorena, \& Astiasarán, 2004). Therefore, nutritional and health concerns have evidenced the need to reduce salt concentrations or replace $\mathrm{NaCl}$ by salt substitutes, such as $\mathrm{KCl}$ or $\mathrm{MgSO}_{4}$ (Aaslyng, Vestergaard, \& Koch, 2014; O'Flynn, Cruz-Romero, Troy, Mullen, \& Kerry, 2014; Rubio, Jofre, Aymerich, Guardia, \& Garriga, 2014). The World Health Organisation (WHO) recommends daily salt intake values of $5 \mathrm{~g}$, which corresponds to less than $2 \mathrm{~g}$ of sodium, and at least $3.51 \mathrm{~g}$ potassium (WHO., 2003).

Microbiological, physicochemical and/or sensory characteristics of different Mediterranean dry-cured sausages have been studied by several authors. High counts of lactic acid bacteria (LAB) and coagulase-negative staphylococci (CNS) are usually present in traditional fermented sausages, resulting in slightly acidic products (pH 5-6) with good sensory characteristics (Comi et al., 2005; Drosinos et al., 2005; Perez-Cacho, Galan-Soldevilla, Crespo, \& Recio, 2005).

Fatty acid composition is a common way to evaluate the quality and nutritional value of dry-fermented sausages, mainly due to 
health concerns about the quality of the consumed fat (Horcada et al., 2013; Jiménez-Colmenero, Triki, Herrero, Rodríguez-Salas, \& Ruiz-Capillas, 2013; Qiu, Zhao, Sun, Zhou, \& Cui, 2013).

In Mediterranean regions, dry-fermented sausages are traditionally manufactured with pure breed Mediterranean pork meat giving these products particular sensory characteristics and fatty acid composition. In South Portugal, the Alentejano pork is used, however alternatives have been searched in order to reduce production costs without affecting the products' characteristics and consumers' acceptability.

Texture Profile Analysis (TPA) parameters as well as sensory attributes have been evaluated before on dry-fermented meat products (Olivares, Navarro, Salvador, \& Flores, 2010; Rubio et al., 2007) with good correlations between both approaches (Elias et al., 2014).

The aim of the present study was to evaluate the effect of genotype, salt content and calibre on the physicochemical, microbiological, texture and sensory parameters in Portuguese traditional dry-fermented sausages. To our knowledge, this is the first comprehensive study on Portuguese dry-cured meat sausages, considering the three factors mentioned above with an attempt to use a hybrid Iberian $\times$ Duroc pig breed and low salt content.

\section{Materials and methods}

\subsection{Sausage technology and sampling procedures}

For this study, 10 reproductive boars of the "Alentejano" breed were obtained from "Herdade dos Bispos e Outeiro" (Beja, Portugal). The pigs were fed on commercial feed (26\% corn, $20 \%$ wheat, $15 \%$ barley, $13 \%$ wheat bran and $11 \%$ soy pomace, among other minor components) ("Alirações", Alcochete, Portugal) without access to "Montanheira". At slaughtering, boars were approximately five years old and carcasses weighed around $150 \mathrm{~kg}$.

Two Portuguese dry-fermented sausages, namely "Chouriço Preto" (CP) and "Paio Preto" (PP) were used. CP has a horseshoe shape with a variable diameter around $30 \mathrm{~mm}$, whereas PP has a cylindrical shape, a variable length between 20 and $30 \mathrm{~cm}$ and a variable diameter near $45-50 \mathrm{~mm}$. Their calibre is irregular, because natural casings are used. The production process involves mechanically mincing meat, previously cut into cubes measuring approximately $25 \mathrm{~mm}$ and mixed with red pepper (Capsicum annuum L.) paste (2.5\%), water reconstituted dried blood powder $(2: 1(\mathrm{w} / \mathrm{v}))(4 \%)$, garlic (Allium sativum L.) paste (1\%), disodium diphosphate $(0.03 \%)$, pentasodium triphosphate $(0.03 \%), \mathrm{NaNO}_{3}$ $(0.02 \%), \mathrm{KNO}_{3}(0.008 \%)$ and $\mathrm{KNO}_{2}(0.007 \%)$. Red pepper and garlic pastes contain $17 \% \mathrm{NaCl}$. Salt was added in order to obtain approximately $3 \%$ and $5 \%$ total chlorides in the final product. The mixture of meat and other ingredients was stored under controlled conditions at $5{ }^{\circ} \mathrm{C}$ and $90 \%$ relative humidity during $48 \mathrm{~h}$ for ripening. Afterwards, this meat batter was stuffed into natural casings made from the pig's small intestine, with a diameter of 36-38 $\mathrm{mm}$ for $\mathrm{CP}$, and the pig's large intestine (rectum), with a diameter of 50-55 $\mathrm{mm}$ for PP. The drying operation occurs in two phases: sausages are dried first in a smoking room for $48 \mathrm{~h}$ at $18-24^{\circ} \mathrm{C}$ and a relative humidity of $30-60 \%$, with smoke generated by burning oak wood (Quercus ilex L.), the conditions inside the smoking room being influenced by environmental conditions through the chimney; and secondly in cure chambers under controlled conditions at $9{ }^{\circ} \mathrm{C}$ and $80-85 \%$ relative humidity during around 14 days for $\mathrm{CP}$ and 30 days for PP. After processing, sausages were vacuum-packaged in polyamide/polyethylene co-extruded film bags using the packing machine 700 STE-XL (Turbovac, The Netherlands) at the production plant in order to be transferred to the laboratory. Once in the lab, sausages were immediately used for
$\mathrm{pH}, \mathrm{a}_{\mathrm{w}}$ and chlorides measurements, microbiological counts, fatty acids profile, texture profile analysis (TPA) and sensory evaluation.

Three independent batches were prepared with two different genotypes, an Alentejano pig breed and a hybrid Iberian $\times$ Duroc pig breed; two different salt contents in the final product (3 and 5\% $\mathrm{NaCl}$ ); and two products with different calibres (small-CP and large-PP).

\section{2. $\mathrm{pH}, \mathrm{a}_{\mathrm{w}}$ and chlorides determination}

After removing the sausage casings, $\mathrm{pH}$ was determined in accordance with the ISO 2917 (1999) using a pH-meter (Crison 507, Barcelona, Spain). Water activity $\left(\mathrm{a}_{\mathrm{w}}\right)$ measurements were carried out using a hygrometer (Hygroskop Rotronic DT, Zurich, Switzerland) with a WA-40 probe at $25{ }^{\circ} \mathrm{C}$. Total chlorides were quantified according to the ISO 1841 (1996).

\subsection{Microbiological analysis}

In general, the microbiological methods used have been adapted from a previous study (Talon et al., 2007). For microbial counts, $10 \mathrm{~g}$ of each sample were homogenized for $90 \mathrm{~s}$ in a Stomacher Masticator (IUL Instruments, Spain) with $90 \mathrm{~mL}$ peptone water (Scharlau, Spain) and serial tenfold dilutions were made and pour-plated. Total mesophiles counts were made in Tryptone Glucose Extract Agar (Scharlau, Spain), incubating at $30^{\circ} \mathrm{C}$ during $48 \mathrm{~h}$; LAB counts in Man, Rogosa and Sharpe (MRS) Agar (Scharlau, Spain), at $30{ }^{\circ} \mathrm{C}$ for $48 \mathrm{~h}$ under anaerobic conditions in an AnaeroJar (Oxoid, UK) using an AnaeroGen sachet (Oxoid, UK); enterococci counts, in Slanetz and Bartley Agar (Biokar, France), at $37^{\circ} \mathrm{C}$ for $48 \mathrm{~h}$; CNS counts, in Mannitol Salt Agar (MSA) (Biokar, France), at $37^{\circ} \mathrm{C}$ for $48 \mathrm{~h}$; yeasts and moulds in Rose Bengal Chloramphenicol (Scharlau, Spain), at $25^{\circ} \mathrm{C}$ for $48 \mathrm{~h}$. For Escherichia coli counts, inoculum was plated in Tergitol 7 (Biokar, France) supplemented with triphenyltetrazolium chloride (TTC) (Biokar, France) and incubated at $44{ }^{\circ} \mathrm{C}$ for $24 \mathrm{~h}$. For all microbial counts, the results were expressed as $\log \mathrm{cfu}^{-} 1$ means \pm standard deviation.

For the detection of Salmonella, $25 \mathrm{~g}$ of each sample were homogenized with $225 \mathrm{~mL}$ peptone water (Scharlau, Spain) and incubated at $37^{\circ} \mathrm{C}$ for $18 \mathrm{~h}$. Following this pre-enrichment period, $0.1 \mathrm{~mL}$ was inoculated in Rappaport Vassiliadis Broth (Scharlau, Spain) and $1 \mathrm{~mL}$ in Muller-Kauffmann Tetrathionate (MKTT) Broth (Scharlau, Spain) supplemented with iodine solution and Brilliant Green-Novobiocin (Scharlau, Spain) and incubated at $41.5^{\circ} \mathrm{C}$ and $37{ }^{\circ} \mathrm{C}$, respectively. After $24 \mathrm{~h}$ selective enrichment, cultures were streaked onto Xylose Lysine Deoxycholate (XLD) Agar (Scharlau, Spain) and Hektoen Enteric Agar (Scharlau, Spain) plates, incubating at $37^{\circ} \mathrm{C}$ for another $24 \mathrm{~h}$. Both media were checked for the existence of typical colonies, which were smeared onto the surface of a Kligler Iron Agar (Oxoid, UK) slope and the butt stabbed. Positive results were confirmed by serology with the Salmonella $\mathrm{O}$ Antiserum Poly A-I \& Vi (Becton, Dickinson and Company, USA).

\subsection{Fatty acids profile}

Each sausage was cut into pieces and grounded in a mechanical mill, then lyophilized and placed in a glass flask and stored at $4{ }^{\circ} \mathrm{C}$ until use. For the extraction of fatty acids, the sausage samples were extracted using a Dionex 100 accelerated solvent extractor (ASE) (Dionex Corporation, USA) by means of the following procedure: aliquots (approximately $300 \mathrm{mg}$ ) of sausages was combined with $6 \mathrm{~g}$ of drying agent, diatomaceous earth (Dionex Corporation, USA), and the mixture was transferred to a $34 \mathrm{~mL}$ stainless steel extraction cell fitted with two cellulose filters. The total lipid sample was then extracted with a mixture of chloroform/methanol (60:40 (v) 
v)) (Merck, Germany) at $100{ }^{\circ} \mathrm{C}$ and $12.4 \mathrm{MPa}$. Both extraction solvents were of residue analysis grade and were treated with $100 \mathrm{mg} \mathrm{L}^{-1}$ BHT (3,5-di-tert-butyl-4-hydroxytoluene) (Merck, Germany) as an antioxidant. Two static extraction cycles were carried out for 5 min each. The removal of the solvent under vacuum using a Vacobox B-177 (Buchi, Switzerland) equipped with a vacuum controller B-720, a rotavapor R-114 (Buchi, Switzerland) attached to a water bath B-480 afforded a crude residue. Next, the crude residue was dissolved with $1 \mathrm{~mL}$ of chloroform and an aliquot of $100 \mu \mathrm{L}$ were taken into a glass tube and the solvent was removed under a stream of nitrogen. The residue obtained was saponified in methanolic $\mathrm{NaOH}$ solution $(0.5 \mathrm{~N})$ at $70{ }^{\circ} \mathrm{C}$ for $15 \mathrm{~min}$. Fatty acids were then prepared with boron-trifluoride-methanol $\left(10 \mathrm{~g} \mathrm{BF}_{3} \mathrm{~L}^{-1}\right.$ $\mathrm{CH}_{3} \mathrm{OH}$ ) (Merck, Germany) in order to give fatty acids methyl esters (FAMEs) according to the procedure of Morrison and Smith (1964). FAMEs were analysed by gas chromatography in a Hewlett Packard HP 6890 Series GC System (HP, USA) equipped with a split-splitless injector, an auto-sampler, a flame-ionisation detector (FID), an Omegawax 320 fused silica capillary column $(30 \mathrm{~m} \times 0.32 \mathrm{~mm}$ i.d., $0.25 \mu \mathrm{m}$ film thickness) (Supelco, USA) and HPChem software (2002). The chromatographic conditions were as follows: oven temperature ranged from 140 to $240{ }^{\circ} \mathrm{C}$ with a ramping rate of $4{ }^{\circ} \mathrm{C} \mathrm{min}^{-1}$; injection port temperature was $250{ }^{\circ} \mathrm{C}$ and FID was $270{ }^{\circ} \mathrm{C}$. The carrier gas was $(\mathrm{He})$ and flow rate was $1.2 \mathrm{~mL} \mathrm{~min}^{-1}$. FAMEs were identified by comparison of their retention times with known standards (37-component FAME mix, Supelco 47885-U) chromatographed in identical gas chromatography conditions and by the determination of Kovats indexes (as listed in Table 1). For each sample, the relative fatty acid composition was quantified and data presented as percentage weight for fatty acid composition.

\subsection{Texture profile analysis}

Texture Profile Analysis (TPA) using a cylindrical flat-ended plunger (with an area of $1 \mathrm{~cm}^{2}$ ) was performed using a Stable

Table 1

Methyl ester fatty acid derivatives found in dry-fermented sausages from Alentejo.

\begin{tabular}{|c|c|c|c|}
\hline Methyl ester FA derivative & $\mathrm{RT}(\min )$ & LRI- apolar column & LRI- polar column \\
\hline \multirow[t]{2}{*}{$\mathrm{C} 12: 0$} & 4.82 & 1519 & 1807 \\
\hline & & $1527^{\mathrm{a}}$ & $1813^{\mathrm{f}}$ \\
\hline \multirow[t]{2}{*}{$\mathrm{C} 14: 0$} & 10.43 & 1724 & 1911 \\
\hline & & $1727^{c}$ & $2034^{\mathrm{f}}$ \\
\hline \multirow[t]{2}{*}{$\mathrm{C} 16: 0$} & 17.10 & 1930 & 2217 \\
\hline & & $1922^{\mathrm{c}}, 1928^{\mathrm{a}}$ & $2198^{g}$ \\
\hline \multirow[t]{2}{*}{ C16:1 } & 17.70 & 1906 & 2241 \\
\hline & & $1932^{\mathrm{b}}$ & $2237^{\mathrm{g}}$ \\
\hline C17:0 & 19.3 & - & 2319 \\
\hline $\mathrm{C} 17: 1$ & 19.8 & - & 2340 \\
\hline \multirow[t]{2}{*}{ C18:0 } & 21.50 & 2130 & 2424 \\
\hline & & $2125^{\mathrm{c}} ; 2130^{\mathrm{d}}$ & $2405^{g}$ \\
\hline \multirow[t]{2}{*}{ C18:1 } & 21.90 & 2107 & 2444 \\
\hline & & $2103^{b}$ & $2424^{\mathrm{g}}$ \\
\hline \multirow{2}{*}{ C18:2 } & 22.00 & - & 2488 \\
\hline & & & $2472^{g}$ \\
\hline C18:3 & 25.21 & - & 2696 \\
\hline \multirow[t]{2}{*}{$\mathrm{C} 20: 1$} & 26.1 & 2304 & 2649 \\
\hline & & $2279^{e}$ & \\
\hline $\mathrm{C} 21: 1$ & 27.04 & - & 2746 \\
\hline
\end{tabular}

Legend: RT retention time (minutes) in Omegawax column; LRI linear retention indexes; - not found in literature.

a HP5 column, Leffingwell \& Alford, 2005.

b HP-5MS column, Pino, Mesa, Muñoz, Martín, \& Marbot, 2005.

c Adams, 1995.

d HP5 MS column, Lazari, Skaltsa, \& Constantinidis, 2000.

e SE 30 column, Golovnya, Uralets, \& Kuzmenko, 1976.

f DB-WAX column, Choi, 2003.

g ZB-WAX column, Wu, Krings, Zorn, \& Berger, 2005.
Micro System TA-Hdi (Stable Micro Systems, Godalming, England) in accordance with the methodology described by (Caine, Aalhus, Best, Dugan, \& Jeremiah, 2003; Martinez, Salmerón, Guillén, \& Casas, 2004). Tests were carried out at room temperature $\left(20^{\circ} \mathrm{C} \pm 1{ }^{\circ} \mathrm{C}\right)$. The samples were previously cut into slices $1 \mathrm{~cm}$ thick, providing circular samples with a diameter of $2-2.5 \mathrm{~cm}$ for $\mathrm{CP}$ and 4-5 cm for PP, which were compressed twice in two consecutive cycles of $50 \%$ compression with $5 \mathrm{~s}$ intervals between cycles, while the plunger was actioned at a constant speed of $1 \mathrm{~mm} \mathrm{~s}^{-1}$. Force/time curves were obtained in order to calculate the following parameters: hardness, adhesiveness, springiness, cohesiveness, resilience and chewiness.

\subsection{Sensory evaluation}

A panel of 10 qualified judges were selected and trained in accordance with ISO 8586-1 (1993). The panel consisted of five women and five men aged between 38 and 59 years. All assessors evaluated three sausage samples per batch. Sensory evaluation was carried out in a sensory laboratory designed in accordance with ISO 8589 (2007). Whole sausages were cut into slices (3 mm thick) $30 \mathrm{~min}$ before analysis. A sample of six sausages per session, as maximum, was presented in random order. Three slices from each dry-fermented sausage were presented on small white plates denoted with a three-digit random number for sample identification. A descriptive quantitative method was adopted, using a structured scale ranging from 0 (no sensation perceived) to 100 (maximum sensation perceived). The following attributes were considered: colour intensity, off colour, aroma intensity, off aroma, tenderness, succulence, flavour intensity, off flavour, salt perception and overall evaluation. For hardness and salt perception, the optimum value was considered to be 50. Judges rinsed their mouths out with neutral water and ate a cracker during sensory evaluation.

\subsection{Data analysis}

Data are presented as means \pm standard deviation. Statistical analysis was performed using SPSS Statistics 21 software (IBM Corp., Armonk, NY, USA). Analyses of variance (ANOVA) for the factors genotype, salt content and calibre were done. No significant differences were observed between batches, thus the factor batch was not considered and all replicates were analysed together. Since interactions were not significant, one-way ANOVAs were performed for each factor separately. Principal Components Analyses (PCA) were also carried out.

\section{Results}

\subsection{Physicochemical parameters}

Mean pH values vary between 5.02 and 5.48 for all products. In the present study, $a_{w}$ values obtained for all products are low enough $(0.807-0.893)$ to ensure microbiological and biochemical stability. Total chlorides analytical values are generally in accordance with formulation values (Table 2). No significantly different values were obtained for different pig genotype sausages $(P>0.05)$ for both $\mathrm{pH}$ and $\mathrm{a}_{\mathrm{w}}$ (Table 3). Regarding the two salt contents, $\mathrm{pH}$ increases with salt content, whereas $a_{w}$ decreases $(P<0.05)$. Higher salt contents lead to a higher level of soluble protein extraction to the extracellular medium, higher buffer effect and thus higher $\mathrm{pH}$ values. Salt is a depressing agent of $\mathrm{a}_{\mathrm{w}}$ values, decreasing the free water content, and as a consequence the products manufactured with $5 \% \mathrm{NaCl}$ show significantly lower $\mathrm{a}_{\mathrm{w}}$ values $(\mathrm{P}<0.05)$. 
Table 2

Physicochemical characteristics ( $\mathrm{pH}, \mathrm{a}_{\mathrm{w}}$ and chlorides) for "Chouriço Preto" and "Paio Preto", according to genotype and salt content.

\begin{tabular}{llllll}
\hline Product & Genotype & $\mathrm{NaCl}(\%)$ & $\mathrm{pH}$ & $\mathrm{a}_{\mathrm{w}}$ & Chlorides (\%) \\
\hline $\mathrm{CP}$ & $\mathrm{AL}$ & 3 & $5.16 \pm 0.05$ & $0.885 \pm 0.005$ & $3.47 \pm 0.08$ \\
& $\mathrm{AL}$ & 5 & $5.48 \pm 0.11$ & $0.844 \pm 0.019$ & $5.05 \pm 0.30$ \\
& $\mathrm{IDR}$ & 3 & $5.31 \pm 0.03$ & $0.863 \pm 0.009$ & $3.60 \pm 0.15$ \\
& $\mathrm{IDR}$ & 5 & $5.39 \pm 0.04$ & $0.853 \pm 0.013$ & $4.90 \pm 0.16$ \\
$\mathrm{PP}$ & $\mathrm{AL}$ & 3 & $5.02 \pm 0.04$ & $0.850 \pm 0.028$ & $4.31 \pm 0.57$ \\
& $\mathrm{AL}$ & 5 & $5.11 \pm 0.14$ & $0.846 \pm 0.024$ & $5.54 \pm 0.27$ \\
& $\mathrm{IDR}$ & 3 & $5.05 \pm 0.03$ & $0.893 \pm 0.023$ & $3.75 \pm 0.38$ \\
& IDR & 5 & $5.23 \pm 0.04$ & $0.807 \pm 0.008$ & $5.52 \pm 0.20$ \\
\hline
\end{tabular}

Data are given as mean \pm standard deviation.

CP-Chouriço preto; PP-Paio preto; AL-Alentejano; IDR-Iberian $\times$ Duroc.

\subsection{Microbiological analysis}

In general, all products show moderate to high counts of all studied microbial groups: mesophiles, LAB and enterococci about $10^{7} \mathrm{cfu} \mathrm{g}^{-1}$; CNS approximately $10^{4}$ to $10^{6} \mathrm{cfu}^{-1}$ and yeasts between $10^{4}$ to $10^{5} \mathrm{cfu} \mathrm{g}^{-1}$ (Table 4). Moulds, E. coli and Salmonella were not detected. This may indicate low contamination of raw materials and careful observation of the hygiene rules during the manufacturing process.
Regarding the factor genotype (Table 3), significant differences were recorded for mesophiles $(\mathrm{P}<0.05)$, enterococci $(\mathrm{P}<0.001)$ and CNS $(\mathrm{P}<0.05)$. The CNS number was higher in the Alentejano genotype, while the counts for mesophiles and enterococci were lower. The significant differences in enterococci and mesophiles between the two genotypes were probably due to the different slaughtering conditions and transport from the slaughterhouses to the production plant. However, those differences of less than $1 \log$ cfu $^{-1}$ are of in practice of low relevance and are usually related to the heterogeneous distribution of microorganisms in the samples.

Differences in numbers of $L A B$ were observed between the two salt contents $(P<0.05)$, the LAB number decreasing with the increase in salt, which may probably be explained by $a_{w}$, once higher $a_{w}$ values enable an enhanced growth of LAB. Although the differences were not significant, higher numbers of CNS were detected in products with $5 \% \mathrm{NaCl}$, which was expected, since staphylococci are generally salt tolerant.

As to calibre size, there were more CNS in $\mathrm{PP}(\mathrm{P}<0.05)$, whereas the total number of yeasts was higher in $\mathrm{CP}(\mathrm{P}<0.001)$. The higher number of CNS in PP is due to the prolonged ripening time (approximately 30 days). There is an increase in $\mathrm{NaCl}$ concentration along the ripening period as a result of water loss, condition which favours the multiplication of CNS. The higher counts of yeasts in the

Table 3

One-Way ANOVA results for the three factors: calibre, genotype and salt content.

\begin{tabular}{|c|c|c|c|c|c|c|c|c|c|}
\hline \multirow{2}{*}{$\frac{\text { Factors }}{\text { Parameters }}$} & \multicolumn{3}{|l|}{ Calibre } & \multicolumn{3}{|l|}{ Genotype } & \multicolumn{3}{|l|}{ Salt content } \\
\hline & $\mathrm{CP}$ & $\mathrm{PP}$ & Sig. & $\mathrm{AL}$ & IDR & Sig. & $3 \%$ & $5 \%$ & Sig. \\
\hline $\mathrm{pH}$ & $5.34^{a} \pm 0.13$ & $5.10^{b} \pm 0.11$ & $0.000^{*}$ & $5.19 \pm 0.20$ & $5.24 \pm 0.13$ & 0.464 & $5.14 a \pm 0.12$ & $5.30 b \pm 0.17$ & $0.013^{*}$ \\
\hline$a_{w}$ & $0.861 \pm 0.019$ & $0.849 \pm 0.037$ & 0.312 & $0.856 \pm 0.025$ & $0.854 \pm 0.034$ & 0.877 & $0.873^{\mathrm{a}} \pm 0.024$ & $0.838^{b} \pm 0.024$ & $0.002^{*}$ \\
\hline Chlorides & $4.26 \pm 0.77$ & $4.78 \pm 0.87$ & 0.131 & $4.59 \pm 0.87$ & $4.44 \pm 0.86$ & 0.677 & $3.79 \pm 0.45$ & $5.25 \pm 0.36$ & $0.000^{*}$ \\
\hline Mesophiles & $7.428 \pm 0.337$ & $7.371 \pm 0.322$ & 0.678 & $7.251 \mathrm{a} \pm 0.177$ & $7.548 b \pm 0.374$ & $0.021^{*}$ & $7.386 \pm 0.367$ & $7.412 \pm 0.289$ & 0.851 \\
\hline $\mathrm{LAB}$ & $7.587 \pm 0.249$ & $7.556 \pm 0.498$ & 0.845 & $7.464 \pm 0.491$ & $7.679 \pm 0.209$ & 0.178 & $7.747^{\mathrm{a}} \pm 0.211$ & $7.396^{\mathrm{b}} \pm 0.446$ & $0.022^{*}$ \\
\hline Enterococci & $7.429 \pm 0.276$ & $7.366 \pm 0.325$ & 0.613 & $7.203 a \pm 0.206$ & $7.592 b \pm 0.242$ & $0.000^{*}$ & $7.493 \pm 0.278$ & $7.301 \pm 0.294$ & 0.115 \\
\hline CNS & $5.102^{\mathrm{a}} \pm 0.374$ & $5.718^{\mathrm{b}} \pm 0.865$ & $0.034^{*}$ & $5.753 a \pm 0.787$ & $5.067 \mathrm{~b} \pm 0.466$ & $0.016^{*}$ & $5.184 \pm 0.211$ & $5.636 \pm 0.194$ & 0.129 \\
\hline Yeasts & $5.103 a \pm 0.358$ & $4.505 b \pm 0.207$ & $0.000^{*}$ & $4.781 \pm 0.371$ & $4.828 \pm 0.477$ & 0.791 & $4.721 \pm 0.415$ & $4.887 \pm 0.422$ & 0.342 \\
\hline $\mathrm{C} 12: 0$ & $0.140 \pm 0.037$ & $0.092 \pm 0.100$ & $0.000^{*}$ & $0.060 \pm 0.066$ & $0.172 \pm 0.039$ & $0.002^{*}$ & $0.112 \pm 0.077$ & $0.120 \pm 0.082$ & 0.658 \\
\hline $\mathrm{C} 14: 0$ & $2.041 \pm 0.691$ & $2.115 \pm 1.054$ & 0.312 & $1.841 \pm 0.641$ & $2.315 \pm 1.029$ & 0.241 & $2.226 \pm 1.066$ & $1.929 \pm 0.638$ & 0.200 \\
\hline C16:0 & $22.194 \pm 2.636$ & $24.692 \pm 0.939$ & $0.002^{*}$ & $22.530 \pm 2.342$ & $24.355 \pm 1.982$ & 0.429 & $23.542 \pm 2.529$ & $23.343 \pm 2.195$ & 0.732 \\
\hline C16:1 & $2.730 \pm 0.380$ & $2.798 \pm 0.780$ & 0.351 & $2.509 \pm 0.716$ & $3.020 \pm 0.316$ & 0.203 & $2.698 \pm 0.767$ & $2.830 \pm 0.396$ & 0.407 \\
\hline $\mathrm{C} 17: 0$ & $0.291 \pm 0.054$ & $0.358 \pm 0.069$ & 0.223 & $0.325 \pm 0.069$ & $0.325 \pm 0.073$ & 0.899 & $0.328 \pm 0.071$ & $0.322 \pm 0.072$ & 0.955 \\
\hline C17:1 & $0.308 \pm 0.095$ & $0.378 \pm 0.100$ & 0.685 & $0.307 \pm 0.107$ & $0.379 \pm 0.086$ & 0.626 & $0.318 \pm 0.073$ & $0.367 \pm 0.123$ & 0.231 \\
\hline C18:0 & $10.958 \pm 1.505$ & $12.064 \pm 1.029$ & 0.192 & $10.621 \pm 1.098$ & 12.4021 .029 & 0.839 & $11.552 \pm 1.451$ & $11.471 \pm 1.372$ & 0.667 \\
\hline C18:1 & $40.263 \pm 5.119$ & $44.496 \pm 1.120$ & $0.000^{*}$ & $41.853 \pm 4.879$ & $42.906 \pm 3.581$ & 0.331 & $42.444 \pm 3.601$ & $42.315 \pm 4.925$ & 0.678 \\
\hline $\mathrm{C} 18: 2$ & $6.697 \pm 2.849$ & $4.419 \pm 1.596$ & $0.001^{*}$ & $7.492 \pm 2.183$ & $3.624 \pm 0.753$ & $0.000^{*}$ & $5.526 \pm 2.643$ & $5.590 \pm 2.550$ & 0.700 \\
\hline C18:3 & $0.436 \pm 0.261$ & $0.255 \pm 0.128$ & $0.000^{*}$ & $0.490 \pm 0.222$ & $0.201 \pm 0.085$ & $0.001^{*}$ & $0.350 \pm 0.228$ & $0.340 \pm 0.224$ & 0.963 \\
\hline C20:1 & $1.116 \pm 0.303$ & $1.219 \pm 0.321$ & 0.653 & $1.393 \pm 0.258$ & $0.941 \pm 0.151$ & 0.149 & $1.147 \pm 0.281$ & $1.188 \pm 0.348$ & 0.536 \\
\hline $\mathrm{C} 21: 1$ & $0.406 \pm 0.190$ & $0.276 \pm 0.083$ & $0.006^{*}$ & $0.451 \pm 0.151$ & $0.231 \pm 0.056$ & $0.006^{*}$ & $0.350 \pm 0.181$ & $0.333 \pm 0.139$ & 0.587 \\
\hline Hardness (TPA) & $45.179 \pm 18.360$ & $65.349 \pm 22.477$ & $0.000^{*}$ & $43.599 \pm 19.118$ & $66.930 \pm 20.172$ & $0.000^{*}$ & $49.906 \pm 17.722$ & $60.622 \pm 26.014$ & $0.009^{*}$ \\
\hline Adhesiveness (TPA) & $-3.176 \pm 2.699$ & $-4.831 \pm 2.748$ & $0.001^{*}$ & $-2.649 \pm 1.901$ & $-5.359 \pm 2.980$ & $0.000^{*}$ & $-3.556 \pm 2.641$ & $-4.452 \pm 2.974$ & 0.083 \\
\hline Cohesiveness (TPA) & $0.584 \pm 0.057$ & $0.611 \pm 0.050$ & $0.006^{*}$ & $0.594 \pm 0.056$ & $0.602 \pm 0.054$ & 0.420 & $0.593 \pm 0.054$ & $0.602 \pm 0.056$ & 0.407 \\
\hline Springiness (TPA) & $0.827 \pm 0.109$ & $0.896 \pm 0.067$ & $0.000^{*}$ & $0.858 \pm 0.089$ & $0.865 \pm 0.104$ & 0.678 & $0.849 \pm 0.099$ & $0.875 \pm 0.093$ & 0.139 \\
\hline Resilience (TPA) & $0.150 \pm 0.028$ & $0.163 \pm 0.035$ & $0.034^{*}$ & $0.163 \pm 0.036$ & $0.149 \pm 0.026$ & $0.017^{*}$ & $0.154 \pm 0.027$ & $0.159 \pm 0.036$ & 0.358 \\
\hline Chewiness (TPA) & $21.997 \pm 10.025$ & $36.077 \pm 13.686$ & $0.000^{*}$ & $22.722 \pm 11.467$ & $35.352 \pm 13.266$ & $0.000^{*}$ & $25.691 \pm 10.813$ & $32.383 \pm 15.777$ & $0.008^{*}$ \\
\hline Colour intensity & $75 \pm 12$ & $79 \pm 13$ & $0.012^{*}$ & $78 \pm 13$ & $75 \pm 12$ & 0.077 & $76 \pm 11$ & $77 \pm 13$ & 0.446 \\
\hline Off colour & $1 \pm 3$ & $0 \pm 0$ & $0.038^{*}$ & $1 \pm 3$ & $0 \pm 1$ & 0.133 & $1 \pm 3$ & $0 \pm 2$ & 0.259 \\
\hline Marbled & $55 \pm 21$ & $73 \pm 18$ & $0.000^{*}$ & $58 \pm 22$ & $70 \pm 19$ & $0.000^{*}$ & $66 \pm 19$ & $62 \pm 23$ & 0.133 \\
\hline Aroma intensity & $68 \pm 12$ & $74 \pm 13$ & $0.002^{*}$ & $71 \pm 13$ & $70 \pm 13$ & 0.685 & $73 \pm 13$ & $69 \pm 13$ & $0.039^{*}$ \\
\hline Off aroma & $1 \pm 3$ & $0 \pm 2$ & 0.116 & $1 \pm 3$ & $0 \pm 2$ & 0.266 & $1 \pm 2$ & $1 \pm 3$ & 0.296 \\
\hline Hardness & $55 \pm 12$ & $52 \pm 8$ & $0.048^{*}$ & $51 \pm 11$ & $55 \pm 10$ & $0.002^{*}$ & $53 \pm 10$ & $54 \pm 11$ & 0.729 \\
\hline Fibrousness & $30 \pm 26$ & $22 \pm 25$ & $0.015^{*}$ & $26 \pm 26$ & $26 \pm 26$ & 0.812 & $25 \pm 26$ & $27 \pm 26$ & 0.517 \\
\hline Succulence & $62 \pm 15$ & $66 \pm 15$ & $0.033^{*}$ & $66 \pm 15$ & $63 \pm 16$ & 0.132 & $66 \pm 16$ & $62 \pm 14$ & 0.109 \\
\hline Taste intensity & $69 \pm 13$ & $75 \pm 13$ & $0.001^{*}$ & $71 \pm 13$ & $71 \pm 13$ & 0.872 & $72 \pm 15$ & $71 \pm 12$ & 0.541 \\
\hline Off taste & $1 \pm 5$ & $0 \pm 2$ & 0.059 & $1 \pm 5$ & $1 \pm 3$ & 0.146 & $1 \pm 4$ & $1 \pm 3$ & 0.594 \\
\hline Salt perception & $53 \pm 6$ & $57 \pm 8$ & $0.000^{*}$ & $56 \pm 7$ & $55 \pm 7$ & 0.333 & $54 \pm 6$ & $57 \pm 8$ & $0.004^{*}$ \\
\hline Overall evaluation & $68 \pm 12$ & $74 \pm 11$ & $0.000^{*}$ & $70 \pm 12$ & $71 \pm 12$ & 0.689 & $72 \pm 12$ & $69 \pm 12$ & 0.095 \\
\hline
\end{tabular}

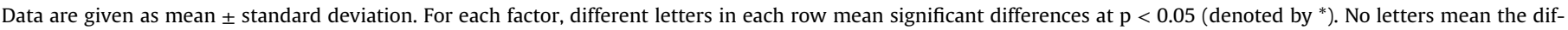
ferences between treatments were not significant.

$\mathrm{CP}$-Chouriço preto; PP-Paio preto; AL-Alentejano; IDR-Iberian $\times$ Duroc. 
Table 4

Microbial counts for "Chouriço Preto" and "Paio Preto", according to genotype and salt content.

\begin{tabular}{|c|c|c|c|c|c|c|c|}
\hline Product & Genotype & $\mathrm{NaCl}(\%)$ & Mesophiles & $\mathrm{LAB}$ & Enterococci & CNS & Yeasts \\
\hline \multirow[t]{4}{*}{$\mathrm{CP}$} & $\mathrm{AL}$ & 3 & $7.3 \pm 0.0$ & $7.7 \pm 0.1$ & $7.2 \pm 0.1$ & $5.1 \pm 0.1$ & $4.8 \pm 0.4$ \\
\hline & $\mathrm{AL}$ & 5 & $7.2 \pm 0.2$ & $7.3 \pm 0.2$ & $7.2 \pm 0.2$ & $5.5 \pm 0.3$ & $5.2 \pm 0.1$ \\
\hline & IDR & 3 & $7.5 \pm 0.6$ & $7.6 \pm 0.2$ & $7.7 \pm 0.2$ & $4.6 \pm 0.1$ & $5.1 \pm 0.6$ \\
\hline & IDR & 5 & $7.6 \pm 0.2$ & $7.7 \pm 0.3$ & $7.6 \pm 0.3$ & $5.2 \pm 0.1$ & $5.3 \pm 0.2$ \\
\hline \multirow[t]{4}{*}{ PP } & $\mathrm{AL}$ & 3 & $7.3 \pm 0.2$ & $7.8 \pm 0.3$ & $7.3 \pm 0.2$ & $6.0 \pm 1.0$ & $4.5 \pm 0.1$ \\
\hline & $\mathrm{AL}$ & 5 & $7.2 \pm 0.3$ & $7.0 \pm 0.8$ & $7.0 \pm 0.3$ & $6.4 \pm 0.9$ & $4.6 \pm 0.3$ \\
\hline & IDR & 3 & $7.4 \pm 0.5$ & $7.8 \pm 0.2$ & $7.8 \pm 0.0$ & $5.0 \pm 0.3$ & $4.5 \pm 0.2$ \\
\hline & IDR & 5 & $7.6 \pm 0.1$ & $7.6 \pm 0.1$ & $7.3 \pm 0.2$ & $5.4 \pm 0.7$ & $4.4 \pm 0.1$ \\
\hline
\end{tabular}

Data are given as mean \pm standard deviation

Values are expressed in $\log _{10} \mathrm{cfu} / \mathrm{g}$.

CP-Chouriço preto; PP-Paio preto; AL-Alentejano; IDR-Iberian $\times$ Duroc.

smaller calibre sausages may partly explain the significantly higher $\mathrm{pH}$ values in these products, likely due to their proteolytic activity. Another possible explanation for the higher number of yeasts in $\mathrm{CP}$ may be the larger oxygen presence, and consequently higher redox potential, inside these sausages, compared to PP (data not shown).

\subsection{Fatty acid composition}

SFA contents ranged between 33.5 and $42.5 \%$; MUFA concentrations were about $43.5-50 \%$ and PUFA around 3-10\% (Table 5). The main identified fatty acids were in decreasing order of concentration: oleic (C18:1), palmitic (C16:0), stearic (C18:0), linoleic (C18:2), palmitoleic (C16:1) and linolenic (C18:3) acid.

Regarding the two genotypes, SFA contents were globally lower in Alentejano genotype products (Tables 3 and 5). Moreover, lauric (C12:0) and stearic (C18:0) acids show relatively higher values for the hybrid genotype for both $\mathrm{CP}$ and $\mathrm{PP}(\mathrm{P}<0.001)$. This may either be due to genetic reasons or, in some cases, also to the pigs feeding. On the other hand, the sausages manufactured with Alentejano pig meat had significantly higher contents of MUFA heneicosanoic (21:1) acid, and PUFA linoleic (C18:2) and linolenic (C18:3) acids $(\mathrm{P}<0.001)$, both essential fatty acids for humans for all samples included in the present study, except for linolenic acid in PP with 5\% $\mathrm{NaCl}$. Once again this is probably due not only to genetic, but also to feeding reasons. However, palmitoleic acid (C16:1) values were significantly higher in the hybrid pigs sausages $(\mathrm{P}<0.05)$, possibly related to feed type.

Oleic acid is the major component of the lipid fraction and it does not change significantly with genotype, salt or calibre. However, the lower values found in Alentejano pork sausages are probably due to feeding reasons. Furthermore, for sausages manufactured with Alentejano pig meat, there was a general decrease with the increase of salt content. Nevertheless, significant differences were observed between the two calibres $(P<0.001)$, which might not be expected since they are made of the same mixture. In our opinion, this may be explained either by the different ripening period of the two products and/or by a deficient homogenisation of the meat batters. For example, concerning the four C:18 fatty acids, PP that has a prolonged ripening time, shows a higher content in C:18:0 and C18:1 and lower in C18:2 and C18:3, when compared to $\mathrm{CP}$, which has a shorter ripening time.

\subsection{Texture profile analysis (TPA)}

TPA values are shown in Table 6. Statistical analyses found differences between genotypes regarding the parameters hardness $(P<0.001)$, adhesiveness $(P<0.001)$, resilience $(P<0.05)$ and chewiness $(\mathrm{P}<0.001)$ (Table 3$)$. Hybrid pig meat sausages have shown higher hardness and adhesiveness values, which means that the muscular fibres were more resistant.
Samples with distinct salt concentrations differed significantly in terms of hardness and chewiness $(P<0.05)$. Higher salt contents lead to a higher level of soluble protein extraction to the extracellular medium and thus higher $\mathrm{pH}$ values, which might result in higher losses in water content. This soluble protein contributes to a better binding of the meat batters and for this reason, e. g., cohesiveness values were higher in CP (although not significantly) for products with $5 \% \mathrm{NaCl}$ content.

Considering the two different calibres, all parameters were significantly different $(\mathrm{P}<0.05)$, $\mathrm{PP}$ having higher values than $\mathrm{CP}$. The longer ripening period of higher calibre products, allowing stronger protein binding, could be implicated in those results.

\subsection{Sensory analysis}

The results for the sensory analysis are summarised in Table 7. Considering the ANOVA results for the sensory evaluation, only the attributes marbled $(\mathrm{P}<0.001)$ and hardness $(\mathrm{P}<0.05)$ exhibited significant differences between genotypes (Table 3 ). The sensory panel has given higher scores in hardness for products manufactured from meat of the hybrid breed genotype, which is in agreement with the instrumental textural analysis. Considering the attribute marbled, hybrid breed genotype products were also better rated, probably due to a better distribution of fat, thus resulting in a higher visibility of the intramuscular fat.

The salt content effect was sensed in the attributes aroma intensity and salt perception $(\mathrm{P}<0.05)$. The aroma is more intense in the products with lower salt contents, which might be explained by the enhanced activity of proteolytic and lipolytic enzymes under these low $\mathrm{NaCl}$ conditions, thus increasing the release of volatile compounds in these products.

There are significant differences between the two calibres in all attributes $(\mathrm{P}<0.05)$, with the exception of off aroma and off taste. PP has higher scores in all attributes, particularly in the "overall evaluation" $(P<0.001)$. Since the meat batters were exactly the same, this may be due to slower but more intense proteolytic and lipolytic reactions in the large calibre products, which suffer a longer ripening time.

Our results reveal that generally salt content reduction does not have any negative effects on the sensory acceptability of sausages.

\section{Discussion}

The measured $\mathrm{pH}$ and $\mathrm{a}_{\mathrm{w}}$ values are in the same range, as described before for Mediterranean dry-cured sausages (Benito et al., 2007; Martín, Colín, Aranda, Benito, \& Córdoba, 2007; Vignolo, Fontana, \& Fadda, 2010). Low $a_{w}$ values allow microbiological and biochemical stability of the products (Ricke, Diaz, \& Keeton, 2007); in fact it is considered that values below 0.91 limit 


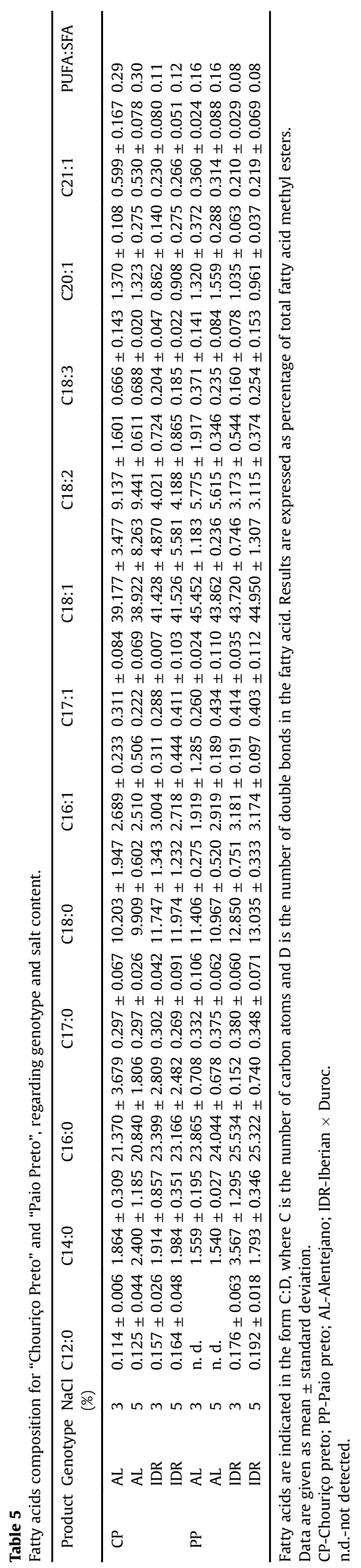

the growth of most pathogenic bacteria (Jay, Loessner, \& Golden, 2005; Vignolo et al., 2010).

The microbial counts for the different groups were in agreement with those obtained previously in other traditional dryfermented sausages (Capita, Llorente-Marigómez, Prieto, \& Alonso-Calleja, 2006; Comi et al., 2005; Drosinos et al., 2005; Rubio et al., 2007).

Even though $\mathrm{pH}$ values were lower in large calibre sausages, higher CNS counts were obtained in PP, which might be explained by the lower (although not significantly different) $a_{w}$ values.

The obtained fatty acid profile basically coincides with that found out by other authors in sausages (Franco, Martinez, Prieto, \& Carballo, 2002) and in pork fat (Cava et al., 1997; Davenel, Riaublanc, Marchal, \& Gandemer, 1999). The main fatty acids in Alentejano pig meat were oleic (C18:1), palmitic (C16:0) and stearic (C18:0) acid, in decreasing order of importance, which agrees with previous studies (Elias \& Carrascosa, 2010). The significantly higher contents of the MUFA and PUFA fatty acids in Alentejano sausages were in agreement with Franco, Escamilla, Garcia, Fontan, and Carballo (2006) referring the effect of genetic and feeding reasons. The fatty acids profile was directly related to the composition of the main food used in the final stage of fattening. Linoleic (C18:2) acid is an essential fatty acid that cannot be synthesized by the pig's organism, it must be supplied in the diet (Wood et al., 2008). Thus, the content in linoleic acid expresses the feed type (Franco et al., 2006). Furthermore, linoleic acid is one of the typical fatty acids to be easily oxidised (Kim, Lee, Pyun, Kim, \& Lee, 2014) and the product from linoleic acid oxidation used for parameter of lipid oxidation in meat (Gandemer, 2002). Alentejano pigs are reared in extensive systems and fattened mainly with acorn (Lopez-Bote, 1998), which is rich in oleic and linoleic fatty acids (Cava et al., 1997). Considering this pig breed, mean oleic acid content is usually around $50 \%$ for fat from fresh meat and meat products (Elias \& Carrascosa, 2010; Horcada et al., 2013; Tejerina, García-Torres, Cabeza de Vaca, Vázquez, \& Cava, 2012). However, despite the observed low oleic acid values, there are reports of similar or even lower values in Iberian pig carcasses and pork sausages (Franco et al., 2006). The recommended ratio PUFA/SFA is 0.4 or above (Wood et al., 2008). In the studied samples, the PUFA/SFA ratio is 0.08-0.30 (Table 5), which means that the obtained values were below the recommended ones, but were similar to those obtained by other authors (Schmid, Collomb, \& Hadorn, 2009). Those results corroborate the idea that the nutritional value of Alentejano and Iberian pig breeds fat is mainly due to its oleic acid richness and not to the ratio PUFA/SFA.

The concentration of most flavour compounds has been reported to increase throughout the ripening period (Ansorena, Astiasarán, \& Bello, 2000; Misharina, Andreenkov, \& Vashchuk, 2001; Sunesen, Dorigoni, Zanardi, \& Stahnke, 2001), although Viallon et al. (1996) described the opposite. The higher CNS values may be responsible for the higher acceptability of PP, since CNS are essential for flavour development (Beck, Hansen, \& Lauritsen, 2004; Olesen, Meyer, \& Stahnke, 2004; Tjener, Stahnke, Andersen, \& Martinussen, 2004b), through the conversion of free fatty acids, particularly in slow ripened products (Tjener, Stahnke, Andersen, \& Martinussen, 2004a). Furthermore, the higher content in linoleic and linolenic acids also contributes to flavour (Chizzolini, Novelli, \& Zanardi, 1998). Double bonds are easier to oxidise and thus PUFA react faster than MUFA or SFA, turning into aldehydes and other compounds important for aroma formation (Brewer, 2010; James \& James, 2010). Linoleic and linolenic acids in specific have been described as being particularly prone to oxidation (Lorenzo, 2014).

TPA compression parameters have been used before in meat products, such as sausages, to evaluate quality of end product or to select the best formulation. The range of TPA values observed in the 
Table 6

Texture profile analysis for "Chouriço Preto" and "Paio Preto", according to genotype and salt content.

\begin{tabular}{|c|c|c|c|c|c|c|c|c|}
\hline Product & Genotype & $\mathrm{NaCl}(\%)$ & Hardness $(\mathrm{N})$ & Adhesiveness ( $\mathrm{N} \mathrm{sec)}$ & Cohesiveness & Springiness (mm) & Resilience & Chewiness $(\mathrm{N} / \mathrm{mm})$ \\
\hline \multirow[t]{4}{*}{$\mathrm{CP}$} & $\mathrm{AL}$ & 3 & $29.391 \pm 10.127$ & $-1.476 \pm 0.674$ & $0.579 \pm 0.055$ & $0.798 \pm 0.082$ & $0.167 \pm 0.023$ & $13.834 \pm 5.593$ \\
\hline & $\mathrm{AL}$ & 5 & $33.312 \pm 13.917$ & $-1.604 \pm 0.690$ & $0.613 \pm 0.061$ & $0.856 \pm 0.098$ & $0.165 \pm 0.029$ & $17.621 \pm 7.545$ \\
\hline & IDR & 3 & $60.216 \pm 12.427$ & $-4.346 \pm 3.317$ & $0.557 \pm 0.054$ & $0.812 \pm 0.135$ & $0.129 \pm 0.018$ & $28.124 \pm 10.466$ \\
\hline & IDR & 5 & $57.796 \pm 11.794$ & $-5.277 \pm 2.612$ & $0.586 \pm 0.048$ & $0.844 \pm 0.114$ & $0.138 \pm 0.020$ & $28.408 \pm 7.044$ \\
\hline \multirow[t]{4}{*}{ PP } & $\mathrm{AL}$ & 3 & $51.704 \pm 13.169$ & $-3.832 \pm 1.925$ & $0.601 \pm 0.038$ & $0.885 \pm 0.056$ & $0.152 \pm 0.026$ & $27.748 \pm 8.006$ \\
\hline & $\mathrm{AL}$ & 5 & $59.988 \pm 19.565$ & $-3.681 \pm 2.302$ & $0.580 \pm 0.065$ & $0.893 \pm 0.087$ & $0.169 \pm 0.057$ & $31.683 \pm 13.276$ \\
\hline & IDR & 3 & $58.313 \pm 15.783$ & $-4.567 \pm 2.785$ & $0.636 \pm 0.037$ & $0.899 \pm 0.070$ & $0.166 \pm 0.024$ & $33.058 \pm 8.256$ \\
\hline & IDR & 5 & $91.393 \pm 17.710$ & $-7.245 \pm 2.501$ & $0.627 \pm 0.036$ & $0.906 \pm 0.057$ & $0.164 \pm 0.021$ & $51.818 \pm 10.517$ \\
\hline
\end{tabular}

Data are given as mean \pm standard deviation.

Units: mm-millimetre; N-Newton; sec-second.

CP-Chouriço preto; PP-Paio preto; AL-Alentejano; IDR-Iberian $\times$ Duroc.

Table 7

Sensory acceptability of "Chouriço Preto" and "Paio Preto", regarding genotype and salt content.

\begin{tabular}{|c|c|c|c|c|c|c|c|c|c|c|c|c|c|c|}
\hline Product & Genotype & $\begin{array}{l}\mathrm{NaCl} \\
(\%)\end{array}$ & $\begin{array}{l}\text { Colour } \\
\text { intensity }\end{array}$ & $\begin{array}{l}\text { Off } \\
\text { colour }\end{array}$ & Marbled & $\begin{array}{l}\text { Aroma } \\
\text { intensity }\end{array}$ & $\begin{array}{l}\text { Off } \\
\text { aroma }\end{array}$ & Hardness & Fibrousness & Succulence & $\begin{array}{l}\text { Taste } \\
\text { intensity }\end{array}$ & $\begin{array}{l}\text { Off } \\
\text { taste }\end{array}$ & $\begin{array}{l}\text { Salt } \\
\text { perception }\end{array}$ & $\begin{array}{l}\text { Overall } \\
\text { evaluation }\end{array}$ \\
\hline \multirow[t]{4}{*}{$\mathrm{CP}$} & $\mathrm{AL}$ & 3 & $77 \pm 11$ & $2 \pm 5$ & $50 \pm 16$ & $72 \pm 12$ & $2 \pm 4$ & $49 \pm 13$ & $30 \pm 29$ & $65 \pm 16$ & $69 \pm 16$ & $2 \pm 8$ & $52 \pm 5$ & $67 \pm 14$ \\
\hline & $\mathrm{AL}$ & 5 & $77 \pm 13$ & $1 \pm 3$ & $46 \pm 21$ & $65 \pm 13$ & $1 \pm 2$ & $55 \pm 10$ & $31 \pm 25$ & $62 \pm 13$ & $68 \pm 10$ & $2 \pm 4$ & $55 \pm 7$ & $67 \pm 12$ \\
\hline & IDR & 3 & $73 \pm 8$ & $0 \pm 2$ & $70 \pm 16$ & $71 \pm 12$ & $0 \pm 0$ & $58 \pm 11$ & $26 \pm 24$ & $63 \pm 18$ & $71 \pm 13$ & $0 \pm 1$ & $53 \pm 5$ & $72 \pm 10$ \\
\hline & IDR & 5 & $73 \pm 14$ & n. d. & $55 \pm 20$ & $67 \pm 11$ & $1 \pm 4$ & $56 \pm 14$ & $32 \pm 26$ & $59 \pm 12$ & $66 \pm 12$ & $1 \pm 4$ & $53 \pm 8$ & $65 \pm 12$ \\
\hline \multirow[t]{4}{*}{ PP } & $\mathrm{AL}$ & 3 & $80 \pm 14$ & n. d. & $67 \pm 17$ & $75 \pm 12$ & $0 \pm 1$ & $53 \pm 7$ & $24 \pm 26$ & $68 \pm 14$ & $74 \pm 15$ & $0 \pm 2$ & $57 \pm 9$ & $74 \pm 9$ \\
\hline & $\mathrm{AL}$ & 5 & $79 \pm 12$ & n. d. & $71 \pm 20$ & $74 \pm 13$ & $1 \pm 2$ & $46 \pm 10$ & $19 \pm 24$ & $68 \pm 14$ & $76 \pm 10$ & $0 \pm 1$ & $59 \pm 7$ & $74 \pm 10$ \\
\hline & IDR & 3 & $75 \pm 11$ & $0 \pm 1$ & $78 \pm 16$ & $73 \pm 14$ & $0 \pm 0$ & $51 \pm 5$ & $18 \pm 25$ & $68 \pm 16$ & $74 \pm 14$ & $1 \pm 3$ & $54 \pm 4$ & $75 \pm 13$ \\
\hline & IDR & 5 & $81 \pm 13$ & n. d. & $77 \pm 16$ & $72 \pm 13$ & $0 \pm 2$ & $56 \pm 6$ & $25 \pm 27$ & $61 \pm 15$ & $75 \pm 13$ & $0 \pm 0$ & $59 \pm 8$ & $72 \pm 10$ \\
\hline
\end{tabular}

Data are given as mean \pm standard deviation

n.d.-none detected.

CP-Chouriço preto; PP-Paio preto; AL-Alentejano; IDR-Iberian $\times$ Duroc.

present study are similar to that reported by other authors (Garcia, Caceres, \& Selgas, 2006; Herrero et al., 2008; Herrero et al., 2007).

Previous studies had already evaluated the sensory quality of Portuguese dry-fermented sausages, with all tested products and treatments receiving high scores from the panellists (Elias \& Carrascosa, 2013; Elias et al., 2014).

For a global view, a PCA was performed on microbial counts and physicochemical parameters, such as $\mathrm{pH}, \mathrm{a}_{\mathrm{w}}$ and total chlorides content, by calibre, genotype and salt content. PCA was able to identify three principal components that accounted for $76.91 \%$ of the total variance. Fig. 1 represents the factorial biplot defined by the two principal components 1 and 2 that explain $63.37 \%$ of the

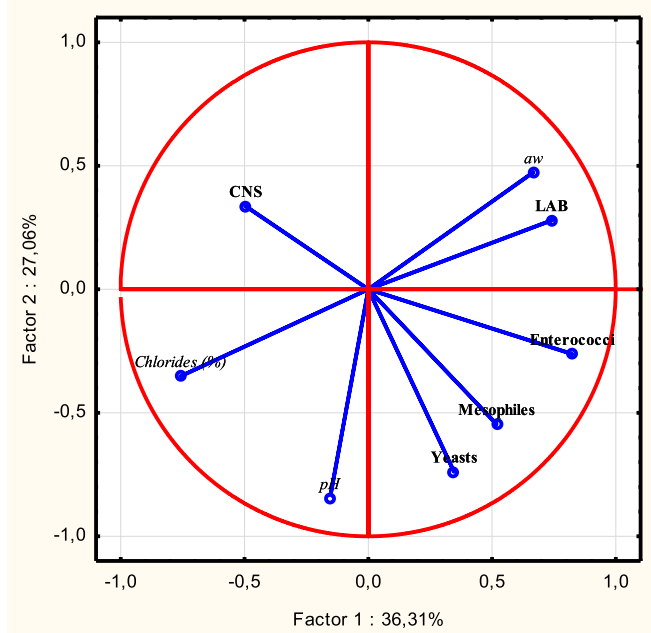

Fig. 1. Principal component analysis (PCA) for physiochemical and microbiological parameters-projection of variables in the factor-plane, considering two factors. total variance. PC1 is the most important factor accounting for $36.31 \%$ of the variance distinguishing samples according to salt content, while PC2 accounted for $27.06 \%$ and separates between technological and spoilage flora. PC1 established an association between $a_{w}, L A B$, mesophiles, enterococci and yeasts, while PC2 relates $\mathrm{a}_{\mathrm{w}}$ to both $L A B$ and CNS counts. PCA projection of variables revealed a very close relationship between $\mathrm{a}_{w}$ and $L A B$, both positioned on the same quadrant of the biplot (Fig. 1).

The association between instrumental and sensory evaluation of texture was also analysed by a PCA using the following parameters: hardness, cohesiveness, adhesiveness, springiness, resilience and

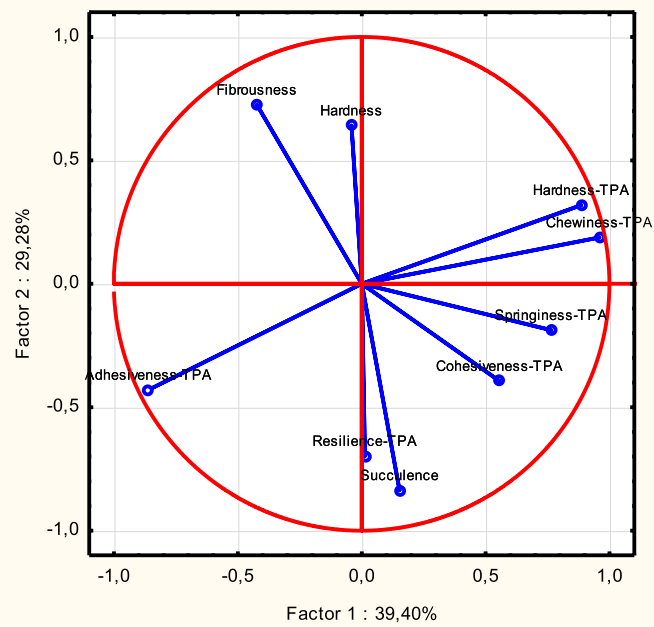

Fig. 2. Principal component analysis (PCA) for textural parameters as determined by TPA and sensory evaluation-projection of variables in the factor-plane, considering two factors. 
chewiness, as evaluated by the TPA test, and hardness, succulence and fibrousness, as perceived by the panellists (Fig. 2). Two principal components were able to explain $68.67 \%$ of the total variance observed. PC1, the most important factor accounting for $39.40 \%$ of the variance, seems to separate the two different sausage calibres, while PC2 accounted for only $29.28 \%$ and distinguishes harder and fibrous products from succulent ones. PCA projection of variables revealed a very close relationship between for example hardness and chewiness, evaluated by TPA, and between hardness and fibrousness, as sensed by the panellists, each two variables located on the same quadrant of the biplot (Fig. 2). The later finding evidences that the panellists recognise as harder the more fibrous sausages. Furthermore, considering PC1, all TPA parameters calculated from hardness show positive values, whereas adhesiveness, an area measured with a traction force, appears isolated with negative values. Besides, resilience is closer to succulence, which means that the higher the resilience the more easily the sample returns to the initial position, which will lead to a more enjoyable sensation in the mouth, stimulating the production of saliva and consequently causing the sensation food succulence. On the other hand, the ability of the sample to return to its initial form after the "bite" leads to a slow and agreeable water release, accompanied by an increased feeling of succulence.

\section{Conclusions}

The present study is the first comprehensive research on Portuguese dry-fermented meat sausages, comparing pig genotypes, salt contents and sausage calibre. The studied products have shown low levels of oleic acid content, despite the fat of the Alentejano genotype being known for its richness in oleic acid. The use of hybrid genotype meat in the manufacture of these products, traditionally made exclusively of Alentejano pig meat, does not affect their sensory properties. Moreover, salt reduction does not negatively affect the quality and acceptability of sausages, which means that the main goal of our study was achieved, since salt content was reduced, without the addition of any salt substitutes, mostly because of the aroma value and flavour components of the formula. Finally, the distinct sausage calibres, only distinguished by size and shape, showed differences, particularly in the sensory analysis with the panellists generally favouring PP.

\section{Acknowledgements}

This work was supported by national funds through project PRODER 13.021 (QREN/PRODER/Medida 4.1), FEDER Funds through the Operational Programme for Competitiveness Factors-COMPETE and National Funds through FCT-Fundação para a Ciência e a Tecnologia under the Strategic Projects PEst-C/AGR/UI0115/2011 and PEst-OE/AGR/UI0115/2014 and Programa Operacional Regional do Alentejo (InAlentejo) ALENT-07-0262-FEDER-001871 (Laboratório de Biotecnologia Aplicada e Tecnologias Agro-Ambientais). The authors thank PALADARES ALENTEJANOS Lda., Q-Staff, Consultoria, Lda., A. Oliveira and G. Pias for their collaboration.

\section{References}

Aaslyng, M. D., Vestergaard, C., \& Koch, A. G. (2014). The effect of salt reduction on sensory quality and microbial growth in hotdog sausages, bacon, ham and salami. Meat Science, 96(1), 47-55.

Adams, R. P. (1995). Identification of essential oil components by gas chromatography/ mass spectrometry. Carol Stream, Illinois, USA: Allured Publishing Corporation.

Ansorena, D., Astiasarán, I., \& Bello, J. (2000). Changes in volatile compounds during ripening of chorizo de Pamplona elaborated with Lactobacillus plantarum and Staphylococcus carnosus. Food Science and Technology International, 6(6), 439-447.
Beck, H. C., Hansen, A. M., \& Lauritsen, F. R. (2004). Catabolism of leucine to branched-chain fatty acids in Staphylococcus xylosus. Journal of Applied Microbiology, 96(5), 1185-1193.

Benito, M. J., Martín, A., Aranda, E., Pérez-Nevado, F., Ruiz-Moyano, S., \& Córdoba, M. G. (2007). Characterization and selection of autochthonous lactic acid bacteria isolated from traditional iberian dry-fermented salchichón and chorizo sausages. Journal of Food Science, 72(6), M193-M201.

Brewer, S. (2010). Technological quality of meat for processing. In F. Toldrá (Ed.) Handbook of meat processing (pp. 25-42). Ames, Iowa, USA: Wiley-Blackwell.

Caine, W. R., Aalhus, J. L., Best, D. R., Dugan, M. E. R., \& Jeremiah, L. E. (2003). Relationship of texture profile analysis and Warner-Bratzler shear force with sensory characteristics of beef rib steaks. Meat Science, 64(4), 333-339.

Capita, R., Llorente-Marigómez, S., Prieto, M., \& Alonso-Calleja, C. (2006). Microbiological profiles, $\mathrm{pH}$, and titratable acidity of chorizo and Salchichón (Two Spanish dry fermented sausages) manufactured with ostrich, deer, or pork meat. Journal of Food Protection, 69(5), 1183-1189.

Cava, R., Ruiz, J., López-Bote, C., Martin, L., Garcia, C., Ventanas, J., et al. (1997). Influence of finishing diet on fatty acid profiles of intramuscular lipids, triglycerides and phospholipids in muscles of the Iberian pig. Meat Science, 45(2), 263-270.

Chizzolini, R., Novelli, E., \& Zanardi, E. (1998). Oxidation in traditional mediterranean meat products. Meat Science, 49(Supplement 1), S87-S99.

Choi, H.-S. (2003). Character impact odorants of Citrus Hallabong [(C. unshiu Marcov x C. sinensis Osbeck) x C. reticulata Blanco] cold-pressed peel oil. Journal of Agricultural and Food Chemistry, 51(9), 2687-2692.

Comi, G., Urso, R., Iacumin, L., Rantsiou, K., Cattaneo, P., Cantoni, C., et al. (2005) Characterisation of naturally fermented sausages produced in the North East of Italy. Meat Science, 69(3), 381-392.

Davenel, A., Riaublanc, A., Marchal, P., \& Gandemer, G. (1999). Quality of pig adipose tissue: relationship between solid fat content and lipid composition. Meat Science, 51(1), 73-79.

Desmond, E. (2006). Reducing salt: a challenge for the meat industry. Meat Science 74(1), 188-196.

Drosinos, E. H. Mataragas, M. Xiraphi, N. Moschonas, G. Gaitis, F., \& Metaxopoulos, J. (2005). Characterization of the microbial flora from a traditional Greek fermented sausage. Meat Science, 69(2), 307-317.

Elias, M., \& Carrascosa, A. V. (2010). Characterisation of the Paio do Alentejo, a traditional Portuguese Iberian sausage, in respect to its safety. Food Control, 21(1), 97-102.

Elias, M., \& Carrascosa, A. V. (2013). Physicochemical, microbiological and sensory changes during storage in "Paio do Alentejo", a traditional Portuguese Iberian sausage. Fleischwirtschaft, 94(4), 109-114.

Elias, M., Potes, M. E., Roseiro, L. C., Santos, C., Gomes, A., \& Agulheiro-Santos, A. C. (2014). The effect of starter cultures on the Portuguese traditional sausage "Paio do alentejo" in terms of its sensory and textural characteristics and polycyclic aromatic hydrocarbons profile. Journal of Food Research, 3(3), 45-56.

Farkas, J. (2007). Physical methods of food preservation. In R. P. Doyle, \& R. L. Buchanan (Eds.), Food microbiology: Fundamentals and frontiers (3rd ed.) (pp. 685-712). Washington, D. C.: ASM Press.

Franco, I., Escamilla, M. C., Garcia, J., Fontan, M. C. G., \& Carballo, J. (2006). Fatty acid profile of the fat from Celta pig breed fattened using a traditional feed: effect of the location in the carcass. Journal of Food Composition and Analysis, 19(8), 792-799.

Franco, I., Martinez, A., Prieto, B., \& Carballo, J. (2002). Total and free fatty acids content during the ripening of artisan and industrially manufactured "Chorizo de cebolla". Grasas Y Aceites, 53(4), 403-413.

Gandemer, G. (2002). Lipids in muscles and adipose tissues, changes during processing and sensory properties of meat products. Meat Science, 62(3), 309-321.

Garcia, M. L., Caceres, E., \& Selgas, M. D. (2006). Effect of inulin on the textural and sensory properties of mortadella, a Spanish cooked meat product. International Journal of Food Science and Technology, 41(10), 1207-1215.

Golovnya, R. V., Uralets, V. P., \& Kuzmenko, T. E. (1976). Characterization of fatty acid methyl esters by gas chromatography on siloxane liquid phases. Journal of Chromatography A, 121(1), 118-121.

Herrero, A. M., de la Hoz, L., Ordóñez, J. A., Herranz, B., Romero de Ávila, M. D., \& Cambero, M. I. (2008). Tensile properties of cooked meat sausages and their correlation with texture profile analysis (TPA) parameters and physico-chemical characteristics. Meat Science, 80(3), 690-696.

Herrero, A. M., Ordóñez, J. A., de Ávila, R., Herranz, B., de la Hoz, L., \& Cambero, M. I. (2007). Breaking strength of dry fermented sausages and their correlation with texture profile analysis (TPA) and physico-chemical characteristics. Meat Science, 77(3), 331-338.

Horcada, A., Fernández-Cabanás, V. M., Polvillo, O., Botella, B., Dolores Cubiles, M. Pino, R., et al. (2013). Feasibility of use of fatty acid and triacylglycerol profiles for the authentication of commercial labelling in Iberian dry-cured sausages. Talanta, 117, 463-470.

INE. (2012). Estatísticas da Produção Industrial 2011. In INE (Ed.), Estatísticas oficiais. Lisboa: Instituto Nacional de Estatística.

ISO 1841 (1996). Meat and meat products. Determination of chloride content.

ISO 2917 (1999). Meat and meat products. Determination of the pH (Reference method).

ISO 8586-1 (1993). Sensory analysis-General guidance for the selection, training and monitoring of assessors-Part 1: Selected assessors.

ISO 8589 (2007). Sensory analysis-General guidance for the design of test rooms.

James, C., \& James, S. J. (2010). Freezing/Thawing. In F. Toldrá (Ed.), Handbook of meat processing (pp. 105-124). Ames, Iowa, USA: Wiley-Blackwell. 
Jay, J. M., Loessner, M. J., \& Golden, D. A. (2005). Intrinsic and extrinsic parameters of foods that affect microbial growth. In Modern food microbiology (7th ed.). (pp. 39-60). New York, USA: Springer.

Jiménez-Colmenero, F., Triki, M., Herrero, A. M., Rodríguez-Salas, L., \& RuizCapillas, C. (2013). Healthy oil combination stabilized in a konjac matrix as pork fat replacement in low-fat, PUFA-enriched, dry fermented sausages. LWT - Food Science and Technology, 51(1), 158-163.

Kim, J.-H., Lee, H.-R., Pyun, C.-W., Kim, S.-K., \& Lee, C.-H. (2014). Changes in physicochemical, microbiological and sensory properties of dry-cured ham in processed sulfur-fed pigs. Journal of Food Processing and Preservation. http:// dx.doi.org/10.1111/jfpp.12293.

Lazari, D. M., Skaltsa, H. D., \& Constantinidis, T. (2000). Volatile constituents of Centaurea pelia DC., C. thessala Hausskn. subsp. drakiensis (Freyn \& Sint.) Georg. and C. zuccariniana DC. from Greece. Flavour and Fragrance Journal, 15(1), 7-11.

Leffingwell, J. C. \& Alford, E. D. (2005). Volatile constituents of perique tobacco. Electronic Journal of Environmental, Agricultural and Food Chemistry, 4(2), 899-915.

Lopez-Bote, C. J. (1998). Sustained utilization of the Iberian pig breed. Meat Science, 49(Supplement 1), S17-S27.

Lorenzo, J. M. (2014). Changes on physico-chemical, textural, lipolysis and volatile compounds during the manufacture of dry-cured foal "cecina". Meat Science, 96(1), 256-263.

Martín, A., Colín, B., Aranda, E., Benito, M. J., \& Córdoba, M. G. (2007). Characterization of Micrococcaceae isolated from Iberian dry-cured sausages. Meat Science, 75(4), 696-708.

Martinez, O., Salmerón, J., Guillén, M. D., \& Casas, C. (2004). Texture profile analysis of meat products treated with commercial liquid smoke flavourings. Food Control, 15(6), 457-461.

Misharina, T. A., Andreenkov, V. A., \& Vashchuk, E. A. (2001). Changes in the composition of volatile compounds during aging of dry-cured sausages. Applied Biochemistry and Microbiology, 37(4), 413-418.

Montville, T. J., \& Chikindas, M. L. (2007). Biopreservation of foods. In R. P. Doyle, \& R. L. Buchanan (Eds.), Food microbiology: Fundamentals and frontiers (3rd ed.). (pp. 747-764). Washington, D. C.: ASM Press.

Morrison, W. R., \& Smith, L. M. (1964). Preparation of fatty acid methyl esters and dimethylacetals from lipids with boron fluoride-methanol. Journal of Lipid Research, 5(4), 600-608.

Muguerza, E., Gimeno, O., Ansorena, D., \& Astiasarán, I. (2004). New formulations for healthier dry fermented sausages: a review. Trends in Food Science \& Technology, 15(9), 452-457.

O'Flynn, C. C., Cruz-Romero, M. C., Troy, D., Mullen, A. M., \& Kerry, J. P. (2014). The application of high-pressure treatment in the reduction of salt levels in reduced-phosphate breakfast sausages. Meat Science, 96(3), 1266-1274.

Olesen, P. T., Meyer, A. S., \& Stahnke, L. H. (2004). Generation of flavour compounds in fermented sausages-the influence of curing ingredients, Staphylococcus starter culture and ripening time. Meat Science, 66(3), 675-687.

Olivares, A., Navarro, J. L., Salvador, A., \& Flores, M. (2010). Sensory acceptability of slow fermented sausages based on fat content and ripening time. Meat Science, 86(2), 251-257.

Perez-Cacho, M. P. R., Galan-Soldevilla, H., Crespo, F. L., \& Recio, G. M. (2005). Determination of the sensory attributes of a Spanish dry-cured sausage. Meat Science, 71(4), 620-633.
Pino, J. A., Mesa, J., Muñoz, Y., Martín, M. P., \& Marbot, R. (2005). Volatile components from mango (Mangifera indica L.) cultivars. Journal of Agricultural and Food Chemistry, 53(6), 2213-2223.

Qiu, C., Zhao, M., Sun, W., Zhou, F., \& Cui, C. (2013). Changes in lipid composition, fatty acid profile and lipid oxidative stability during Cantonese sausage processing. Meat Science, 93(3), 525-532.

Ricke, S. C., Diaz, I. Z., \& Keeton, J. T. (2007). Fermented meat, poultry,and fish products. In R. P. Doyle, \& R. L. Buchanan (Eds.), Food microbiology: Fundamentals and frontiers (3rd ed.). (pp. 795-816). Washington, D. C.: ASM Press.

Rubio, R., Jofre, A., Aymerich, T., Guardia, M. D., \& Garriga, M. (2014). Nutritionally enhanced fermented sausages as a vehicle for potential probiotic lactobacilli delivery. Meat Science, 96(2), 937-942.

Rubio, B., Martinez, B., Sanchez, M. J., Garcia-Cachan, M. D., Rovira, J., \& Jaime, I. (2007). Study of the shelf life of a dry fermented sausage "salchichon" made from raw material enriched in monounsaturated and polyunsaturated fatty acids and stored under modified atmospheres. Meat Science, 76(1), 128-137.

Schmid, A., Collomb, M., \& Hadorn, R. (2009). Fatty acid composition of Swiss cooked sausages. Fleischwirtschaft, 89(11), 101-104.

Sunesen, L. O., Dorigoni, V., Zanardi, E., \& Stahnke, L. (2001). Volatile compounds released during ripening in Italian dried sausage. Meat Science, 58(1), 93-97.

Talon, R., Lebert, I., Lebert, A., Leroy, S., Garriga, M., Aymerich, T., et al. (2007). Traditional dry fermented sausages produced in small-scale processing units in mediterranean countries and Slovakia. 1: microbial ecosystems of processing environments. Meat Science, 77(4), 570-579.

Talon, R., Lebert, I., Lebert, A., Leroy, S., Garriga, M., Aymerich, T., et al. (2012). Microbial ecosystem of traditional dry fermented sausages in mediterranean countries and Slovakia. In G. S. Williams (Ed.), Mediterranean ecosystems: Dynamics, management and conservation (pp. 115-127). Nova Science Publishers, Inc.

Tejerina, D., García-Torres, S., Cabeza de Vaca, M., Vázquez, F. M., \& Cava, R. (2012). Effect of production system on physical-chemical, antioxidant and fatty acids composition of Longissimus dorsi and Serratus ventralis muscles from Iberian pig. Food Chemistry, 133(2), 293-299.

Tjener, K., Stahnke, L. H., Andersen, L., \& Martinussen, J. (2004a). A fermented meat model system for studies of microbial aroma formation. Meat Science, 66(1), 211-218.

Tjener, K., Stahnke, L. H., Andersen, L., \& Martinussen, J. (2004b). Growth and production of volatiles by Staphylococcus carnosus in dry sausages: influence of inoculation level and ripening time. Meat Science, 67(3), 447-452.

Viallon, C., Berdagué, J. L., Montel, M. C., Talon, R., Martin, J. F., Kondjoyan, N., et al. (1996). The effect of stage of ripening and packaging on volatile content and flavour of dry sausage. Food Research International, 29(7), 667-674.

Vignolo, G., Fontana, C., \& Fadda, S. (2010). Semidry and dry fermented sausages. In F. Toldrá (Ed.), Handbook of meat processing (pp. 379-398). Ames, Iowa, USA: Wiley-Blackwell.

WHO. (2003). Diet, nutrition and the prevention of chronic disease. Report of a joint WHO/FAO expert consultation. Geneva: World Health Organization (WHO).

Wood, J. D., Enser, M., Fisher, A. V., Nute, G. R., Sheard, P. R., Richardson, R. I., et al. (2008). Fat deposition, fatty acid composition and meat quality: a review. Meat Science, 78(4), 343-358.

Wu, S., Krings, U., Zorn, H., \& Berger, R. G. (2005). Volatile compounds from the fruiting bodies of beefsteak fungus Fistulina hepatica (Schaeffer: Fr.). Food Chemistry, 92(2), 221-226. 